\title{
BLNK wt Allele
}

National Cancer Institute

\section{Source}

National Cancer Institute. BLNK wt Allele. NCI Thesaurus. Code C52374.

Human BLNK wild-type allele is located within 10q23.2-q23.33 and is approximately $80 \mathrm{~kb}$ in length. This allele, which encodes B-cell linker protein, is involved in B-cell receptordependent signal progression. The wild-type allele is essential for B-cell development. 